\title{
Synthesis and Study the Chelating Activity of some Polymers Containing Heterocyclic Rings, The Derivatives from 1,2,4- trizol Levofloxacin acid
}

\section{TAHSEEN SADDAM FANDI AL-MATHKURI ${ }^{1}$, HAMID MOHAMMED SALEH AL-JUBORI ${ }^{2}$ and ALI TAHA SALEH ${ }^{1 *}$}

\author{
${ }^{1}$ Department of Chemistry, Collage of Science, University of Misan, Misan, Iraq. \\ ${ }^{2}$ Collage of Basic Education, University of Tikrit, Tikrit, Iraq. \\ ${ }^{*}$ Corresponding author E-mail: ali_6222@yahoo.com.sg \\ http://dx.doi.org/10.13005/ojc/3404042
}

(Received: May 30, 2018; Accepted: August 05, 2018)

\begin{abstract}
ABSTRAT
The compound 6-amino-5-mercapto-4H-1,2,4-triazol-3-yl)-9-fluoro-3-methyl-10(4-methylpiperazin-1-yl)-2,3-dihydro-7H-[1,4] oxazino[2,3,4-ij] quinolin-7-one (M1) synthesize from the reaction of thiocarbohydrazide with levofloxacin acid by using ethanol as a solvent, phenolic Schiff bases (Z)-9-fluoro-6-(4-((4-hydroxybenzylidene) amino)-5-mercapto4H1,2,4-triazol-3-yl)3-methyl-10-(4-methylpiperazin-1-yl)-2,3-dihydro-7H-[1,4]oxazino[2,3,4-ij] quinolin-7-one $\left(\mathrm{M}_{2}\right)$, (Z)-6-(4-((2,4-dihydroxybenzylidene) amino)-5-mercapto-4H-1,2,4-triazol-3-yl)-9-fluoro-3-methyl10-(4-methylpiperazin-1-yl)-2,3-dihydro-7 H-[1,4] oxazino[2,3,4-ij]quinolin-7-one $\left(\mathrm{M}_{3}\right)$ and $(\mathrm{Z})-6$ (4-((5-chloro-2-hydroxybenzylidene) amino)-5-mercapto-4H-1,2,4-triazol-3-yl)-9-fluoro-3-methyl-10(4-methylpiperazin-1-yl)-2,3-dihydro-7H- $[1,4]$ oxazino[2,3,4-ij] quinolin-7-one $\left(\mathrm{M}_{4}\right)$ were prepared from the reaction of trizol derivative of $\left[\mathrm{M}_{1}\right]$ compound with the appropriate phenolic aldehydes by using ethanol as a solvent. The synthetic Schiff bases used to prepare numbers of phenolic polymers [M5-M7] from the reaction of Schiff bases [M2-M4] with phenol formaldehyde. The analytical efficiency of the synthetic chelating polymers studied by the batch method with different transition metals ions $\left(\mathrm{Cd}^{2+}, \mathrm{Fe}^{3+}, \mathrm{Cu}^{2+}\right)$, in terms of the effect of treatment time and the $\mathrm{pH}$ on the loading capacity of the polymers, controlling the other factors such as temperature, ions concentration and quantity of polymers. The result shows that the capacity of the polymer increased with increasing of the $\mathrm{pH}$ and treating time. The synthetic compounds were characterized by various instrumental techniques like FTIR, 'H-NMR, DTG and TGA studies. These spectral and thermal studies provide very valuable information about the structural features.
\end{abstract}

Keywords: 1,2,4- trizol Levofloxacin acid, Heterocyclic rings, ${ }^{1} \mathrm{H}-\mathrm{NMR}, \mathrm{TGA}$.

\section{INTRODUCTION}

Micro-organisms has reached on alarming level around the world, and the synthesis of new anti-infective compounds has become an urgent need for the treatment of microbial infections. The 1,2,4-triazole nucleus has been incorporated into a wide variety of therapeutically important agents, which mainly displaying antimicrobial activities ${ }^{1}$. Organic compounds incorporating heterocyclic ring systems continue to attract considerable interest due to their wide range of biological activities. Among different five-membered heterocyclic systems 1,2,4Triazoles and 1,3,4-Thiadiazoles and their derivatives

This is an Open Access article licensed under a Creative Commons Attribution-Non Commercial-Share Alike 4.0 International License (https://creativecommons.org/licenses/by-nc-sa/4.0/), which permits unrestricted Non Commercial use, distribution and reproduction in any medium, provided the original work is properly cited. 
have gained importance as they constitute the structural features of many bioactive compounds. It is known that Triazole and Thiadiazole rings are included in the structure of various drugs ${ }^{2,3}$. From these classes of heterocyclic compounds, the synthesis of new derivatives of 1,2,4-triazole-3-thiones and 2-amino-1,3,4-Thiadiazoles has been attracting considerable attention because of various biological properties such as: antibacterial ${ }^{4,5}$, antifungal ${ }^{6}$, antitubercular $^{7}$, antiviral ${ }^{8}$, antioxidant ${ }^{9,10}$, antitumoral ${ }^{8}$, anti-inflammatory ${ }^{11}$, anticonvulsant ${ }^{12}$, etc. In this study, a new Triazole derivative was synthesized by many cyclization reactions, the analytical efficiency of the synthetic chelating polymers studied by the batch method with different transition metals ions $\left(\mathrm{Cd}^{2+}, \mathrm{Fe}^{3+}, \mathrm{Cu}^{2+}\right)$.

\section{MATERIALS AND METHODS}

\section{Syntheses of Triazole compound $\left[\mathrm{M}_{1}\right]$}

A mixture of $(0.36 \mathrm{~g}, 0.001 \mathrm{~mol})$ of levofloxacin and $0.1 \mathrm{~g}(0.001 \mathrm{~mol})$ of thiocarbohydrazide with absolute ethanol as a solvent was refluxed for $6 \mathrm{~h}$ and then cooled and separated by filtration and the solid was recrystallized from ethanol in order to obtain the desired result in the form of crystals with yellow colour and with a yield of (65\%) and melting point $\left(211-213^{\circ} \mathrm{C}\right)$. TLC method was used to determine the purity of the prepared compound.

\section{Syntheses of Shiff base compounds [M2-M4]}

A mixture of $(0.001 \mathrm{~mol}, 0.36 \mathrm{~g})$ of the M1 compound and $(0.001 \mathrm{~mol})$ of the appropriate benzaldehyde derivatives by using the absolute ethanol as a solvent. The reaction mixture was refluxed for $4 \mathrm{~h}$. on a heat source with stirring, then cooled to room temperature. The precipitated was filtered off, washed with water and recrystallized from ethanol. The TLC method was used to determine the purity of the prepared compounds.

Table 1: Some physical properties of prepared compounds $\left[\mathrm{M}_{2}-\mathrm{M}_{4}\right]$

\begin{tabular}{cccccc}
\hline Samples & $\mathrm{R}$ & Formula & m.p. & Yield & Color \\
\hline $\mathrm{M}_{2}$ & $4-\mathrm{OH}$ & $\mathrm{C}_{25} \mathrm{H}_{26} \mathrm{FN}_{3} \mathrm{O}_{6}$ & $226-228$ & $66 \%$ & Brown \\
$\mathrm{M}_{3}$ & $2-\mathrm{OH}, 4-\mathrm{OH}$ & $\mathrm{C}_{25} \mathrm{H}_{26} \mathrm{FN}_{3} \mathrm{O}_{7}$ & $233-235$ & $58 \%$ & Brown \\
$\mathrm{M}_{4}$ & $2-\mathrm{OH}, 5-\mathrm{Cl}$ & $\mathrm{C}_{25} \mathrm{H}_{25} \mathrm{FNO}_{6} \mathrm{Cl}$ & $216-218$ & $63 \%$ & White \\
\hline
\end{tabular}

\section{Preparation of chelating resins [M5-M7]}

In a rotary beaker $(0.003 \mathrm{~mol})$ of prepared compounds (M2-M4) with (0.074 mol) of phenol 12), added a well-mixed formaldehyde mixture $(25 \mathrm{~mL})$ and then raise the $\mathrm{pH}$ to (9-10.5) by adding (10\%) of sodium hydroxide. The mixture refluxed with constant stirring for $4 \mathrm{~h}$. until getting a sticky reddish-brown gel and solvent evaporated. The product was then transferred to a drying oven at a temperature of $120^{\circ} \mathrm{C}$ for $2 \mathrm{~h}$. to complete the calcination. grinding then washed thoroughly with the deionized water to dispose of the residue (un-reactant material) then dried in vacuum until the weight was acquired, the products measured by thermal analysis (TG / (DTG).

\section{Preparation of standard solutions for element ions}

The standard solutions prepared by dissolving the appropriate weights of the metal nitrate in the little amount of water, added $2 \mathrm{ml}$ of concentrated nitric acid or concentrated hydrochloric acid and according to the using salt, then complete the volume to $500 \mathrm{ml}$ using the deionized water. Table 2 show the weights which used for component salts to prepare standard solutions (1000) ppm in metal ion. A certain volume of these ions was diluted to give a concentration of 100 ppm for each ion and in different $\mathrm{pH}$. The $\mathrm{pH}$ was confirmed by using nitric acid solution and ammonium hydroxide solution at a concentration of $1 \mathrm{M}$ for each one.

Table 2: The weights used for the salts of each element required to obtain $500 \mathrm{ml}$ of solutions at a concentration of 1000 ppm

\begin{tabular}{ccc}
\hline No & Formula & Weight in $500 \mathrm{ml}$ \\
\hline 1 & $\mathrm{Cd}\left(\mathrm{NO}_{3}\right)_{2} \cdot 6 \mathrm{H}_{2} \mathrm{O}$ & $2.561 \mathrm{~g}$ \\
2 & $\mathrm{FeCl}_{3}$ & $1.312 \mathrm{~g}$ \\
3 & $\mathrm{Cu}\left(\mathrm{NO}_{3}\right) \cdot 3 \mathrm{H}_{2} \mathrm{O}$ & $1.482 \mathrm{~g}$ \\
\hline
\end{tabular}




\section{RESULTS AND DISCUSSION}

The compounds were prepared according to the steps of the methods mentioned in the section 2 according to the following scheme 1 .
The compound $\left[\mathrm{M}_{1}\right]$ prepared from the reaction of thiocarboohydrazide with levofloxacin acid by reflux and ethanol as solvent as the following mechanic scheme 2
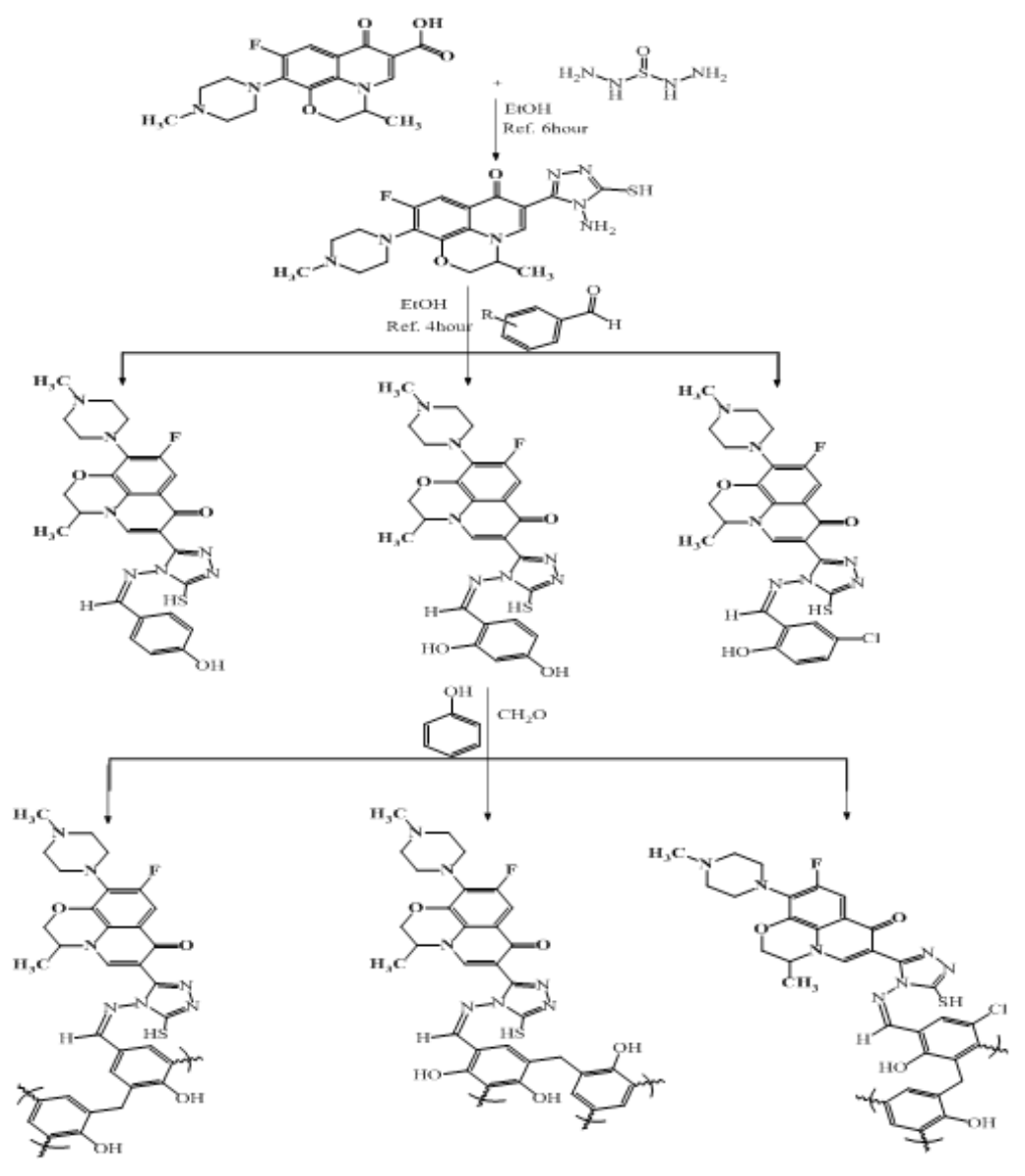

scheme 1<smiles>[R]C(O)C(=O)NNC(=O)NNC(=O)NN</smiles>

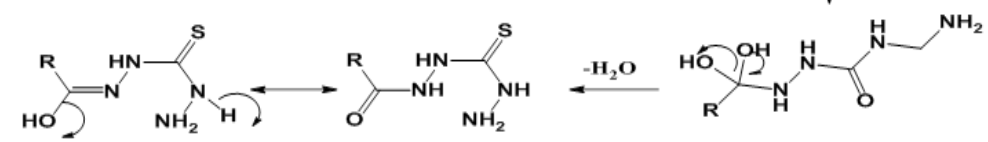
$\downarrow-\mathrm{H}_{2} \mathrm{O}$

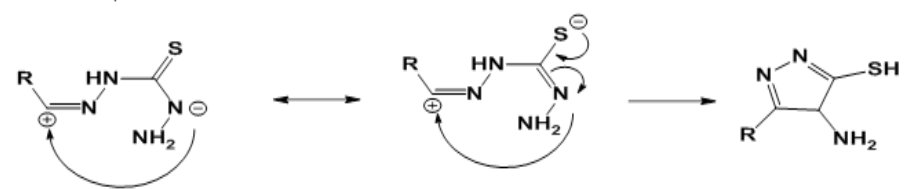

scheme 2 


\section{FTIR Spectra}

\section{FTIR analysis of compound $\left(\mathrm{M}_{1}\right)$}

It was confirmed that the reaction completed by the change in the physical properties such as melting point and color. The FTIR analysis of $\mathrm{M}_{1}$ was observed within the bands at range (3343-3372 $\left.\mathrm{cm}^{-1}\right)$ due to the asymmetric vibration of the $\mathrm{NH}_{2}$ group (Fig.1). A band was also found at the range (3047- $\left.3180 \mathrm{~cm}^{-1}\right)$ due to $\mathrm{Ar}-\mathrm{H}$ and $\mathrm{C}=\mathrm{C}(\mathrm{Ar}-\mathrm{H})$ vibration. A peak at the range $\left(2973-2857 \mathrm{~cm}^{-1}\right)$ due to the pendulous vibration of the $\mathrm{SH}$ series and absorption peak at $\left(1691 \mathrm{~cm}^{-1}\right)$ was found for the extension of the carbonate group $(\mathrm{C}=\mathrm{O})$. A peak at $(1649) \mathrm{cm}^{-1}$ stretching mods of $(\mathrm{C}=\mathrm{N})$, as well as the absorption bands appeared within the range $\left(1560 \mathrm{~cm}^{-1}\right)$ belonging to the fluctuation of the bond $(C=C)$.

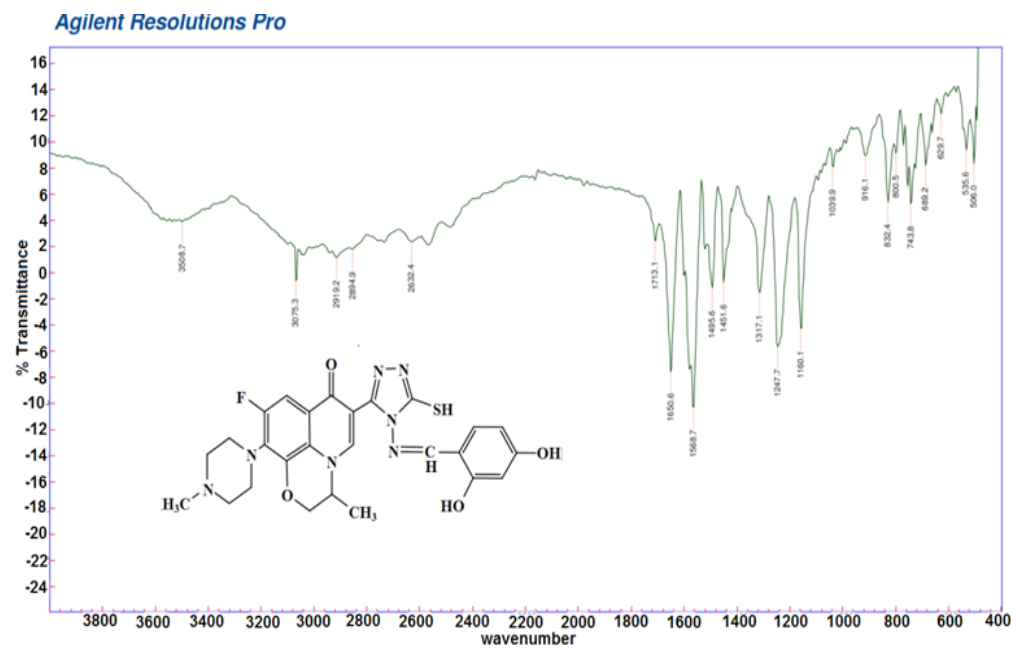

Fig. 1. Infrared spectra of the $\left[\mathrm{M}_{1}\right]$

\section{FTIR analysis of compound $\left(\mathrm{M}_{2}\right.$ and $\left.\mathrm{M}_{4}\right)$}

FTIR spectra are shown in (Fig. 2), The bands at (3464-3508 $\left.\mathrm{cm}^{-1}\right)$ was attributed to the bending mode of the $\mathrm{OH}$ group. The disappearance of the $\mathrm{NH}_{2}$ peak was observed. The spectra showed a band within the range $3011-3122 \mathrm{~cm}^{-1}$ as a result of the vibration of $\mathrm{C}-\mathrm{H}$ and aromatic bands within the range $2919-2894 \mathrm{~cm}^{-1}$ was attributed to the symmetrical symmetry-like- symmetry of $\mathrm{C}-\mathrm{H}$, a peak that the 2631-2634 $\mathrm{cm}^{-1}$ was due to $\mathrm{SH}, 1694-1713$ $\mathrm{cm}^{-1}$ is due to the vibration of the carbonate group $\mathrm{C}=\mathrm{O}$, peaks at1648-1653 $\mathrm{cm}^{-1}$ due to the variation of $\mathrm{C}=\mathrm{N}$ group, Absorption bands appeared within the range $1568-1598 \mathrm{~cm}^{-1}$ belonging to the vibration of the $\mathrm{C}=\mathrm{C}$ bond as shown in Table 3 and (Fig 3). These compounds $\left[\mathrm{M}_{2}, \mathrm{M}_{4}\right]$ were identified using the $\mathrm{H}-\mathrm{NMR}$ technique using DMSO-d6 as a solvent.

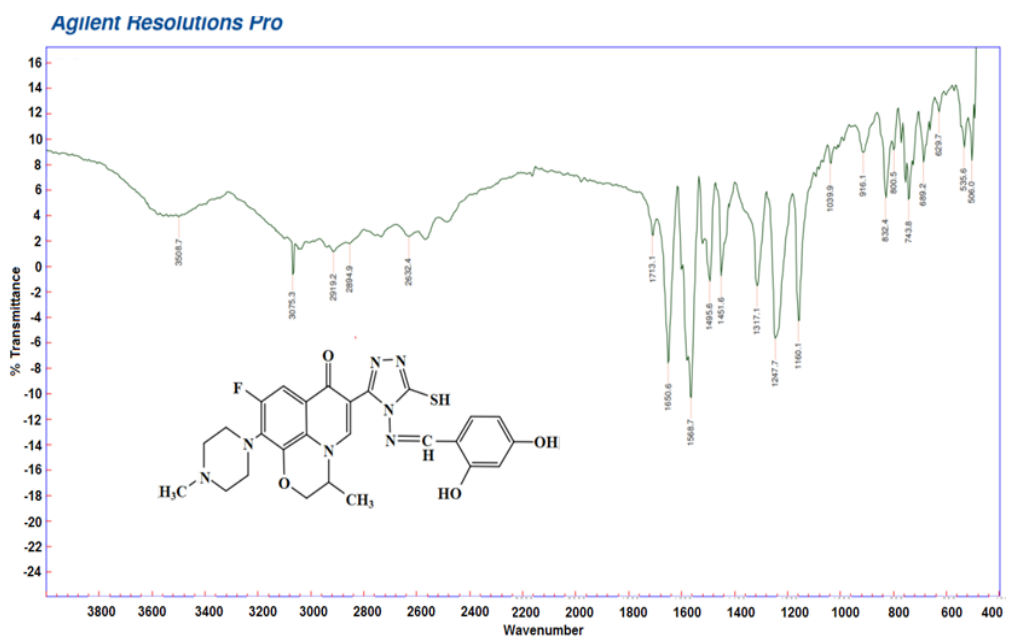

Fig. 2. Infrared spectra of compound $\left[\mathrm{M}_{3}\right]$ 
Table 3: FTIR assignments for the compounds M2, M3 and M4

\begin{tabular}{lccccccc}
\hline No. & $\begin{array}{c}\mathrm{OH} \\
\mathrm{cm}^{-1}\end{array}$ & $\begin{array}{l}\mathrm{Ar}-\mathrm{H} \\
\mathrm{cm}^{-1}\end{array}$ & $\begin{array}{l}\mathrm{C}-\mathrm{H} \\
\mathrm{cm}^{-1}\end{array}$ & $\begin{array}{c}\mathrm{S}-\mathrm{H} \\
\mathrm{cm}^{-1}\end{array}$ & $\begin{array}{l}\mathrm{C}=\mathrm{O} \\
\mathrm{cm}^{-1}\end{array}$ & $\begin{array}{l}\mathrm{C}=\mathrm{N} \\
\mathrm{cm}^{-1}\end{array}$ & $\begin{array}{c}\mathrm{C}=\mathrm{C} \\
\mathrm{cm}^{-1}\end{array}$ \\
\hline $\mathrm{M}_{2}$ & 3464 & 3122 & 2941 & 2634 & 1694 & 1648 & 1582 \\
$\mathrm{M}_{3}$ & 3508 & 3075 & 2919 & 2632 & 1713 & 1650 & 1568 \\
$\mathrm{M}_{4}$ & 3487 & 3011 & 2977 & 2631 & 1702 & 1653 & 1598 \\
\hline
\end{tabular}

\section{${ }^{1} \mathrm{H}$ NMR spectra of (M1)}

The magnetic resonance spectrum of the M1 showed a single signal at $1.22 \mathrm{ppm}$ fraction per million of the $\mathrm{CH}_{3}$ protons (Fig. 3). A single signal at ppm (2.10) was due to the ringing of $\mathrm{N}-\mathrm{CH}_{3}$ protons and singled out as resonant $\left(\mathrm{CH}_{3}\right)$ and $(\mathrm{CH})$ interlocking ring $(\mathrm{CH})$ and other single signalling of protein resonance $\mathrm{O}-\mathrm{CH}_{2}$ group at chemical shift (4.43) ppm and the appearance of a single signal at displacement (5.70) ppm due to the resonance of $\mathrm{NH}_{2}$ proteins and multiple signalling at ppm (7.29-7.70) attributed to aromatic rings (Ar-H) and the emergence of other packages.

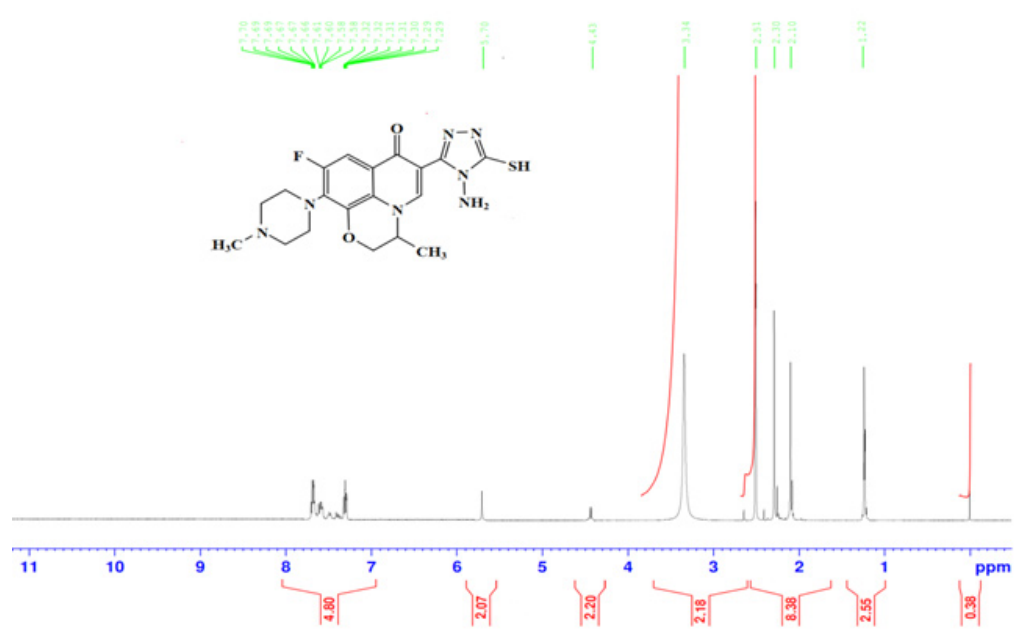

Fig. 3. ${ }^{1} \mathrm{H}-\mathrm{NMR}$ spectra of compound [M1]

\section{${ }^{1} \mathrm{H}$ NMR spectra of (M2)}

The NMR spectrum of the compound showed a single signal at (1.12) ppm due to the resonance of protons $\mathrm{CH}_{3}$ and a single signal at $2.08 \mathrm{ppm}$ due to the resonance of $\mathrm{N}-\mathrm{CH}_{3}$ and single signal at $3.36 \mathrm{ppm}$, the signal was observed in the absence of the monotonous signal of the $\mathrm{NH}_{2}$ (Fig. 4). The spectrum showed a multiple signal at the range (7.02-7.89) ppm due to the Ar-H proton resonance. A single new signal was observed at (8.9) ppm due to isomethene proton resonance $(\mathrm{N}=\mathrm{CH})$ in addition to the emergence of another single new signal at (9.45) ppm belonging to the group $(\mathrm{OH})$.

\section{${ }^{1} \mathrm{H}$ NMR spectra of $\left(\mathrm{M}_{4}\right)$}

The NMR spectrum showed a single signal at (1.87) ppm of protons $\left(\mathrm{CH}_{3}\right)$ and a mono signal at (2.10) ppm due to protons $\left(\mathrm{N}^{-} \mathrm{CH}_{3}\right)$ and a single signal at $3.33 \mathrm{ppm}$ to the proton $(\mathrm{SH})$ (Fig. 4). The spectrum showed a multiple signal at the range (7.01-7.88) ppm due to Ar-H resonance with a new mononuclear signal at $8.59 \mathrm{ppm}$ and a new monochromatic signal at (9.55) ppm belong to the group $(\mathrm{OH})$.

\section{Thermal analysis}

Thermal analyses of the prepared polymers (TG, DTG) were recorded at room temperature $(900 \mathrm{~m})$ and at a heating rate $(\mathrm{min} / 10 \mathrm{~m})$ and in an atmosphere of nitrogen.

Thermodynamic Analysis of Polymers $\left[\mathrm{M}_{5}\right]$

The shapes show the thermodynamic curves (DTG, TGA) of the polymers (Fig. 6). Five 
decomposition phases. The compound showed a weak bond at $100 \mathrm{C}$ and a small loss (3.69\%) due to moisture loss. (14.95\%) as shown by the TG curve and the third decomposition begins loss of $(450-680) \mathrm{m}$
0 and loss rate of $13.69 \%$ and the fourth stage starts loss at (620-470) $\mathrm{m} 0$ loss of $17.025 \%$ ) and the fifth stage shows weak packets (770-720) $\mathrm{m}$ and loss rate of $3.67 \%$ ) through the stages of the loss process.

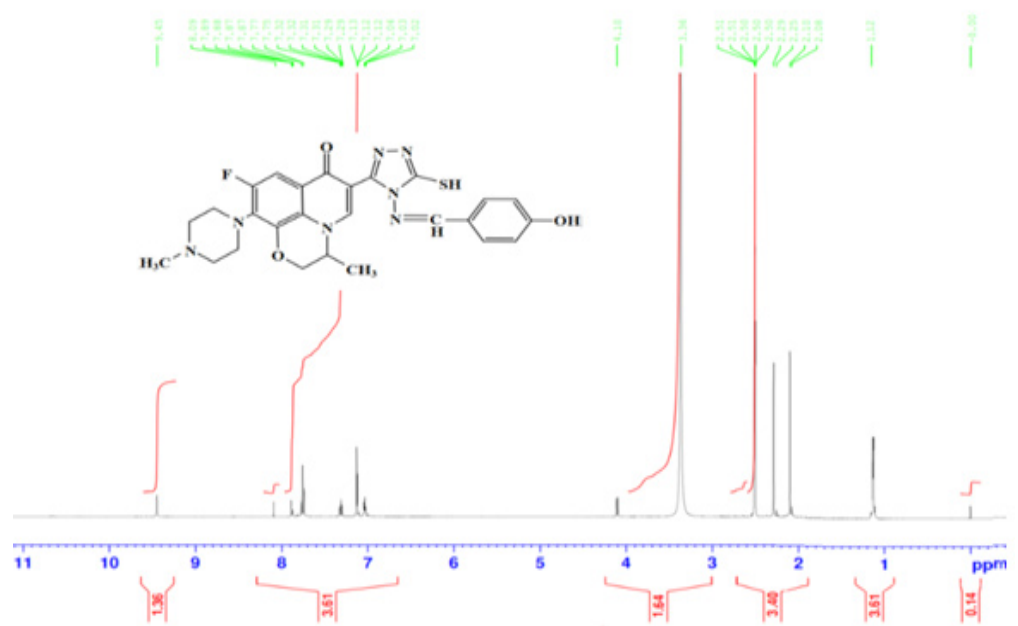

Fig. 4. ${ }^{1} \mathrm{H}-\mathrm{NMR}$ spectra of compound [M2]

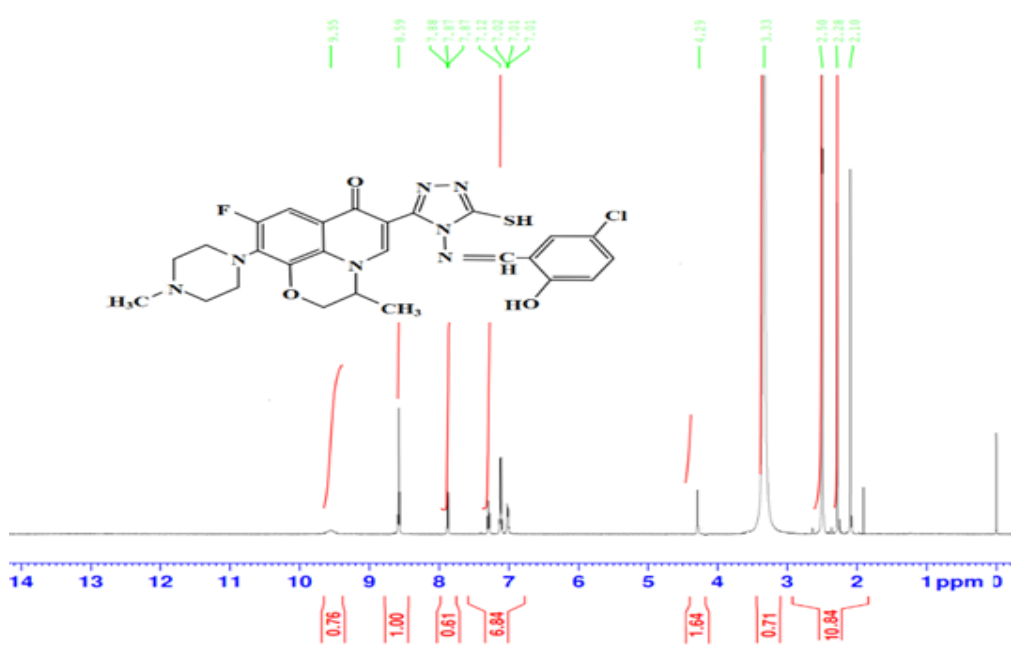

Fig. 5. ${ }^{1} \mathrm{H}-\mathrm{NMR}$ spectra of compound [M4]

\section{Thermal Analysis of Polymer $\left[\mathrm{M}_{7}\right]$}

The shapes show the thermodynamic curves (DTG, TGA) of the polymers (Fig. 7). Three phases of disintegration of the compound showed a weak bond at $100 \mathrm{~m}(0)$ with a low loss rate $(60.25 \%)$ due to moisture loss and loss rate $(6.65 \%)$ as shown by the curve (TG) and the third decomposition begins at $(380-560 \mathrm{~m})$ and loss rate $(12.15 \%)$ through the stages of loss.

\section{Analytical measurements}

A selective study of resins towards elements

The maximum loading capacity of the resins to the studied elements at the maximum treatment time $24 \mathrm{~h}$ and the highest $\mathrm{pH}$ of the metal ion solution, where the solution is clear and non-turbid and at room temperature, is the optimal condition used for the study of selective renal resins. The process is treated with $0.1 \mathrm{~g}$ of resins with element ions, which are 100-ppm in isolation for $24 \mathrm{~h}$ and at the highest acidic function of the element ions solution. The filtration process is performed and the concentration of each ion in the leachate is performed mediated Atomic absorption spectrometry to determine the number of ions associated with different resins studied $\left[\mathrm{M}_{5}-\mathrm{M}_{7}\right]$. 


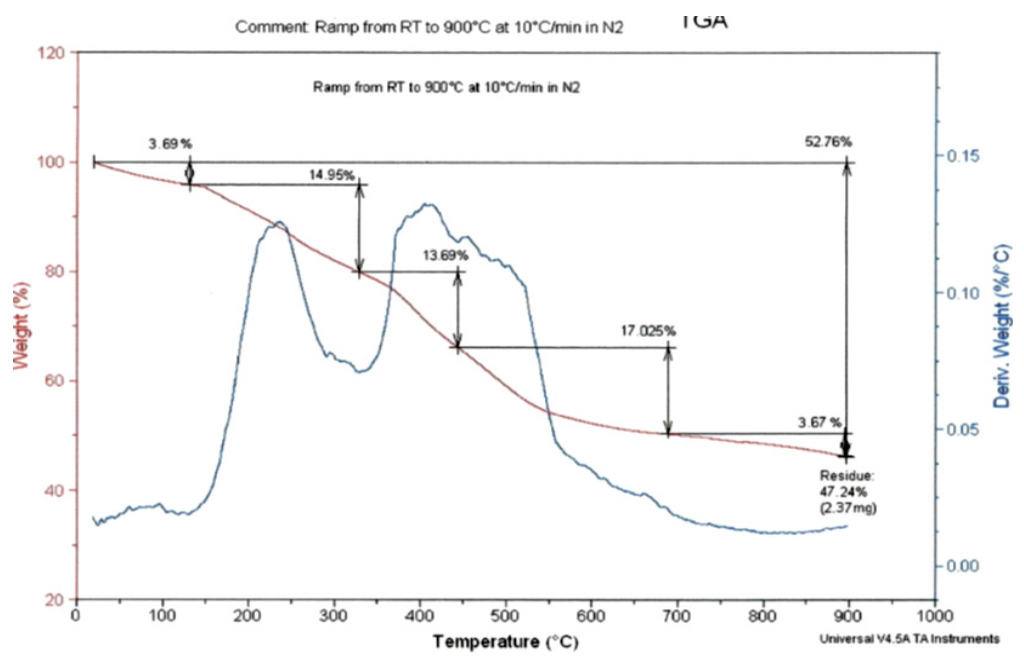

Fig. 6. TG / DTG thermal analysis curve for polymer $\left[\mathrm{M}_{5}\right]$

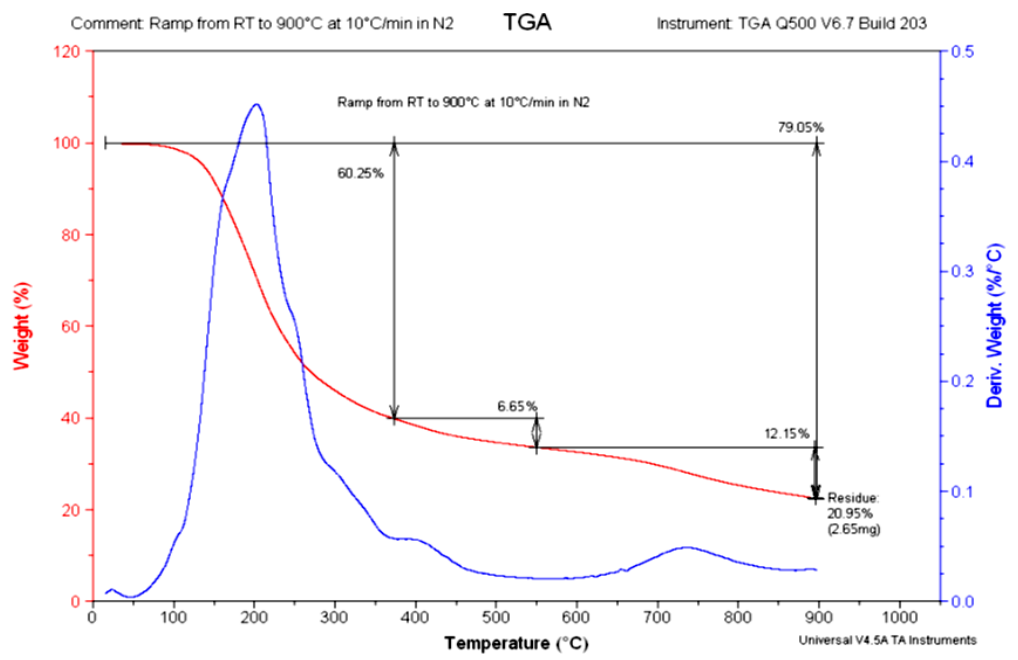

Fig. 7. TG / DTG thermal analysis curve for polymer $\left[\mathrm{M}_{7}\right]$

Effect of transaction time on resins loading capacity

The effect of the treatment time for resins was studied with the ions of the studied ions after each other stabilizing factors, namely the size of the solution and the acidic function, were treated with $(0.1) \mathrm{g}$ of resin with (10) $\mathrm{ml}$ of the element ions solution at $100 \mathrm{ppm}$ for different periods of time ranging from 1 to $24 \mathrm{~h}$ and then the concentration of ions associated with resin was calculated.

\section{Effect of pH function on the load capacity of the composite resin $\left[\mathrm{M}_{5}-\mathrm{M}_{7}\right]$}

The effect of the $\mathrm{pH}$ on the loading capacity was studied by treating $(10 \mathrm{~mL})$ of the ion solution for specific periods of time in each $\mathrm{pH}$ studied with $0.1 \mathrm{~g}$ of resin. The highest loading capacity of most ions is at the highest $\mathrm{pH}$ of the ion solution under study. $\mathrm{Cu}^{2+}, \mathrm{Fe}^{3+}, \mathrm{Cd}^{2+}$.

\section{Study of Analytical Efficiency of Metallic Resins $\left[\mathrm{M}_{5}-\mathrm{M}_{7}\right]$}

Analytical efficiency of the resin towards the studied ions, which includes the two and three charge ions $\left(\mathrm{Cu}^{2+}, \mathrm{Fe}^{3+} \mathrm{Cd}^{2+}\right)$. The ion concentration in these solutions was determined by atomic absorption spectroscopy technique, Concentrate $100 \mathrm{ppm}$ with $0.1 \mathrm{~g}$ of resin and for 24 hours. All ions have shown a significant response to the resin.

The effect of the treatment time on the maximum load capacity of the composite resins $\left[M_{5}-M_{7}\right]$.

The increase in the treatment time 
increases the loading capacity of resins in general for the studied ions. The loading capacity reaches its maximum at the highest treatment time 24 hours. This study was conducted to determine the effect of the processing time on loading capacity. Resins of the ions reach the state of equilibrium almost after 7-8 hours, when all the acidic functions are under study, and the amount of increase in loading capacity becomes slightly until 24 hours of treatment. The effect of the treatment time on the loading capacity of ions resins $\left(\mathrm{Cu}^{2+}, \mathrm{Fe}^{3+}, \mathrm{Cd}^{2+}\right)$ show in tables 4-6 and Figures 8- 16.
Table 4: Number of milligrams of ions $\left(\mathrm{Cu}^{2+}\right.$, $\mathrm{Fe}^{3+}, \mathrm{Cd}^{2+}$, withdrawn by $0.1 \mathrm{~g}$ of the molar resin $\left[\mathrm{M}_{5}\right]$ as a function of time in different $\mathrm{pH}$ Loading Capacity of ion mg (h) ion/gm resin (Time

\begin{tabular}{lcccccc}
\hline Ions & $\mathrm{pH}$ & 1 & 2 & 4 & 10 & 24 \\
\hline $\mathrm{Cd}$ & 3 & 1.6 & 2.2 & 3.5 & 4.3 & 5.8 \\
& 4 & 2.4 & 3.9 & 5.1 & 5.9 & 6.4 \\
$\mathrm{Fe}$ & 1 & 1.2 & 2.7 & 3.6 & 5.1 & 7.4 \\
& 5 & 2.3 & 4.2 & 5.4 & 7.6 & 8.5 \\
$\mathrm{Cu}$ & 4 & 1.7 & 2.8 & 4.2 & 5.8 & 6.3 \\
& 6 & 2.6 & 4.2 & 5.4 & 7.2 & 7.6 \\
\hline
\end{tabular}

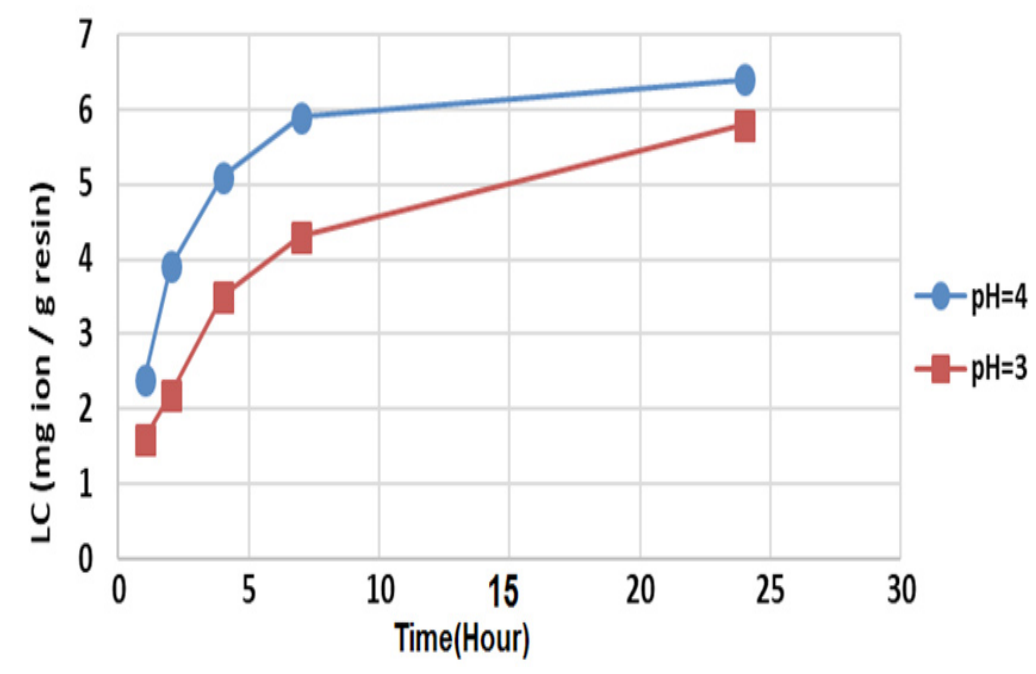

Fig. 8. Number of $\mathrm{mg}$ of ions $\left(\mathrm{Cd}^{2+}\right)$ withdrawn by $(0.1 \mathrm{~g})$ of the polymer $\left[\mathrm{M}_{5}\right]$ as a function of time in different $\mathrm{pH}=3.4$

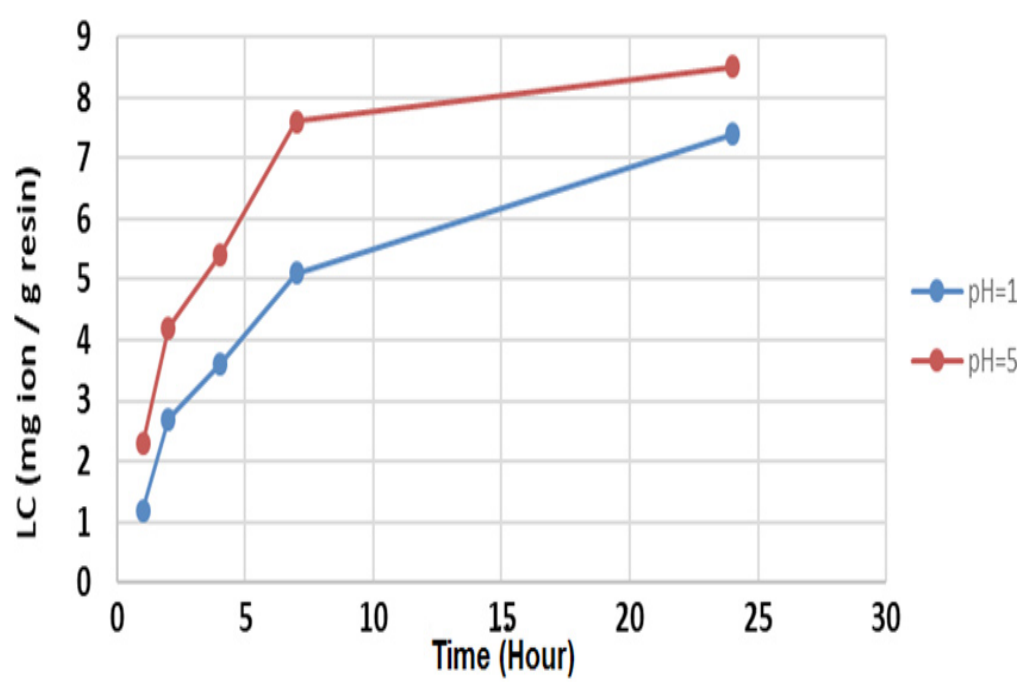

Fig. 9. Number of $\mathrm{mg} /$ ions $\left(\mathrm{Fe}^{3+}\right)$ withdrawn by $(0.1 \mathrm{~g})$ of the polymer $\left[\mathrm{M}_{5}\right]$ as a function of time and different $\mathrm{pH}=1.5$ 


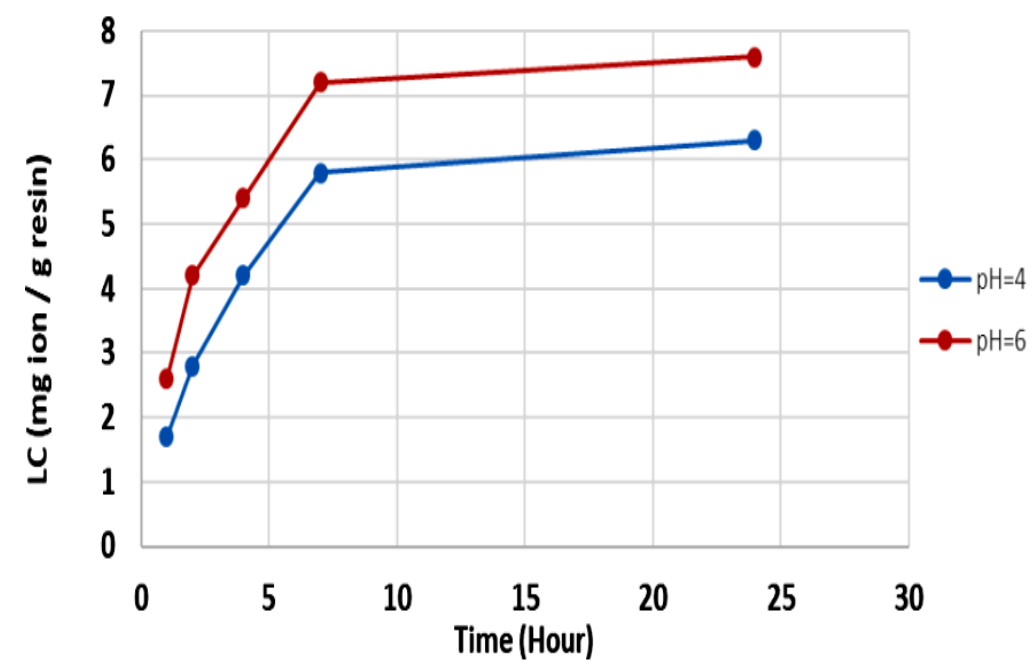

Fig. 10. The number of milligrams of ions $\left(\mathrm{Cu}^{2+}\right)$ drawn by $(0.1 \mathrm{~g})$ of the polymer $\left[\mathrm{M}_{5}\right]$ as a function of time and $\mathrm{pH}=4.6$.

Table 5: Number of milligrams of ions $\left(\mathrm{Cu}^{2+}, \mathrm{Fe}^{3+}, \mathrm{Cd}^{2+}\right)$, withdrawn by $0.1 \mathrm{gm}$ of the molar resin $\left[\mathrm{M}_{6}\right]$ as a function of time and different $\mathrm{pH}$

\begin{tabular}{lllllll}
\hline \multicolumn{6}{c}{ Loading Capacity of ion mg ion/gm resin (Time (h) } \\
\hline Ions & $\mathrm{pH}$ & 1 & 3 & 5 & 8 & 24 \\
\hline \multirow{2}{*}{$\mathrm{Cd}$} & 3 & 1.7 & 2.9 & 3.7 & 5.2 & 6.8 \\
& 6 & 3.4 & 6.1 & 6.8 & 7.5 & 8.4 \\
$\mathrm{Fe}$ & 2 & 1.7 & 3.1 & 4.3 & 6.5 & 7.2 \\
& 6 & 2.5 & 5.9 & 5.7 & 6.8 & 7.2 \\
$\mathrm{Cu}$ & 2 & 1.3 & 3.5 & 4.2 & 5.6 & 6.7 \\
& 5 & 2.4 & 4.3 & 5.9 & 6.7 & 7.4 \\
\hline
\end{tabular}

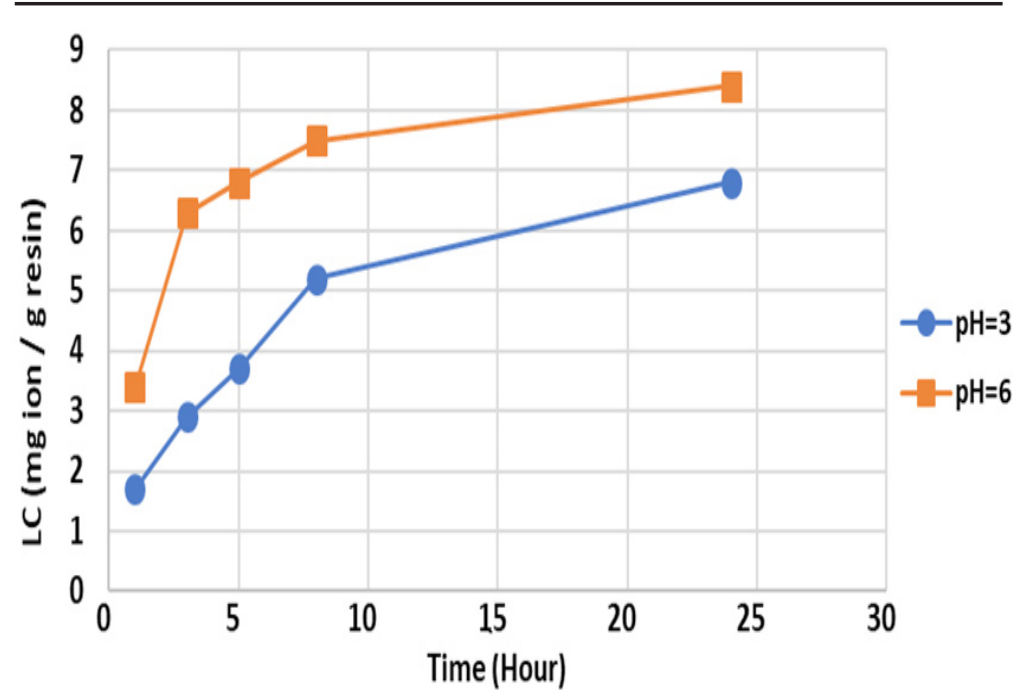

Fig. 11. The number of milligrams of ions $\left(\mathrm{Cd}^{2+}\right)$ drawn by $(0.1 \mathrm{~g})$ of the polymer

$\left[\mathrm{M}_{6}\right]$ as a function of time and $\mathrm{pH}$ 


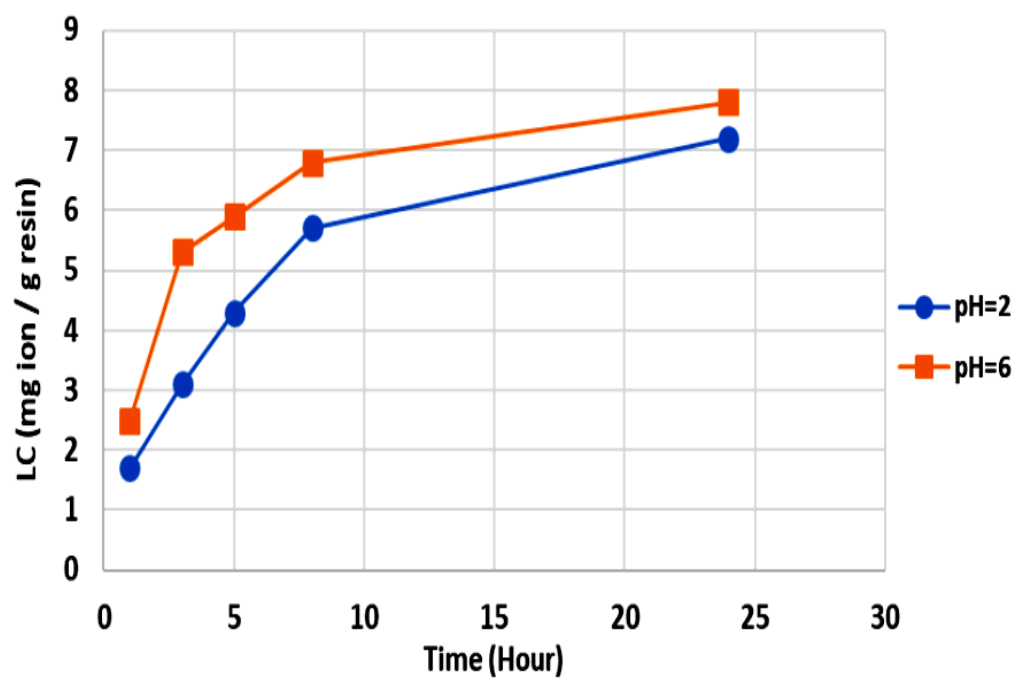

Fig. 12. The number of milligrams of ions $\left(\mathrm{Fe}^{3+}\right)$ drawn by $(0.1 \mathrm{~g})$ of the polymer $\left[\mathrm{M}_{6}\right]$ as a function of time and $\mathrm{pH}$

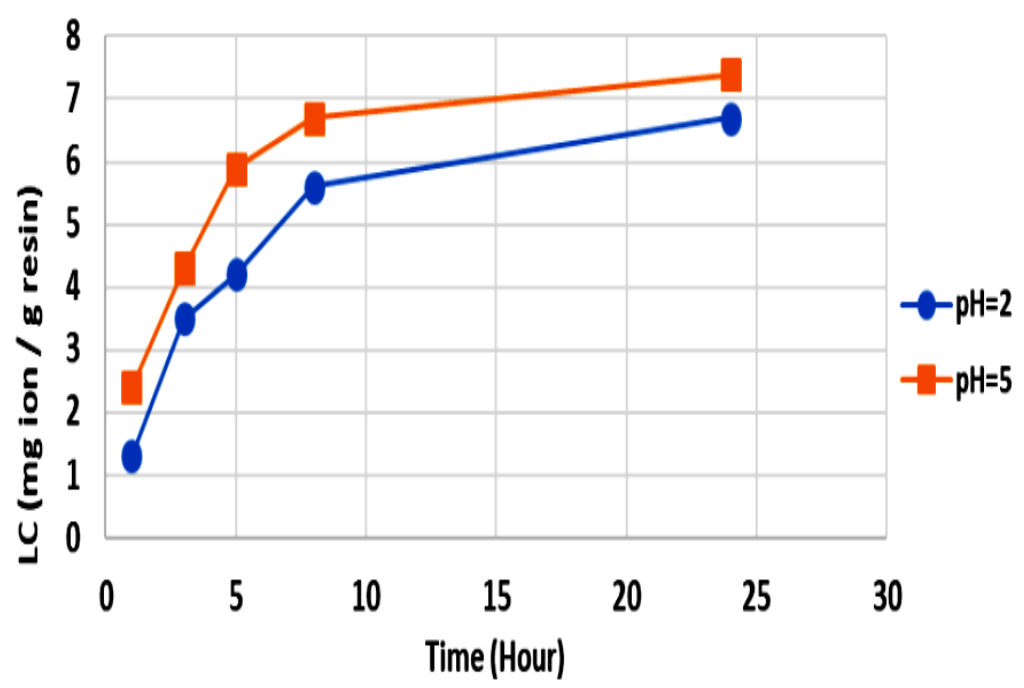

Fig. 13. The number of milligrams of ions $\left(\mathrm{Cu}^{2+}\right)$ drawn by $(0.1 \mathrm{~g})$ of the polymer $\left[\mathrm{M}_{6}\right]$ as a function of time and $\mathrm{pH}$

Table 5: Number of milligrams of ions $\left(\mathrm{Cu}^{2+}, \mathrm{Fe}^{3+}, \mathrm{Cd}^{2+}\right)$, withdrawn by $0.1 \mathrm{~g}$ of the molar resin $\left[\mathrm{M}_{6}\right]$ as a function of time and different $\mathrm{pH}$

\begin{tabular}{lllllll}
\hline & \multicolumn{6}{c}{ Loading Capacity of ion mg ion/gm resin (Time (h) } \\
\hline \multirow{2}{*}{ lons } & $\mathrm{pH}$ & 1 & 3 & 5 & 8 & 24 \\
\hline \multirow{2}{*}{$\mathrm{Cd}$} & 3 & 1.7 & 2.9 & 3.7 & 5.2 & 6.8 \\
& 6 & 3.4 & 6.1 & 6.8 & 7.5 & 8.4 \\
$\mathrm{Fe}$ & 2 & 1.7 & 3.1 & 4.3 & 6.5 & 7.2 \\
& 6 & 2.5 & 5.9 & 5.7 & 6.8 & 7.2 \\
$\mathrm{Cu}$ & 2 & 1.3 & 3.5 & 4.2 & 5.6 & 6.7 \\
& 5 & 2.4 & 4.3 & 5.9 & 6.7 & 7.4 \\
\hline
\end{tabular}




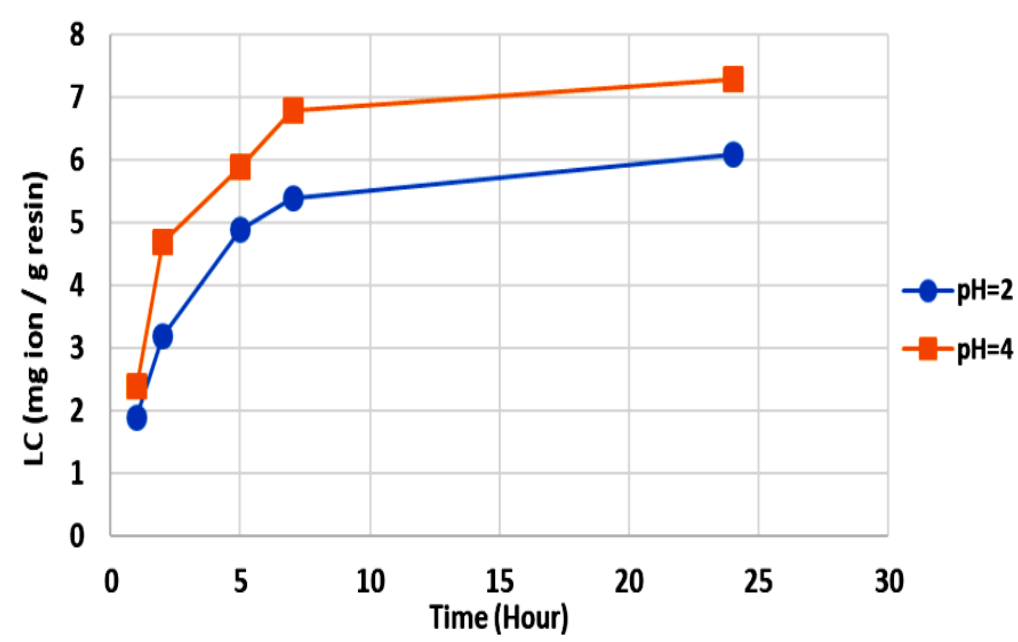

Fig. 14. The number of milligrams of ions $\left(\mathrm{Cd}^{2+}\right)$ withdrawn by $(0.1 \mathrm{~g})$ of the polymer $\left[\mathrm{M}_{7}\right]$ as a function of time and $\mathrm{pH}$

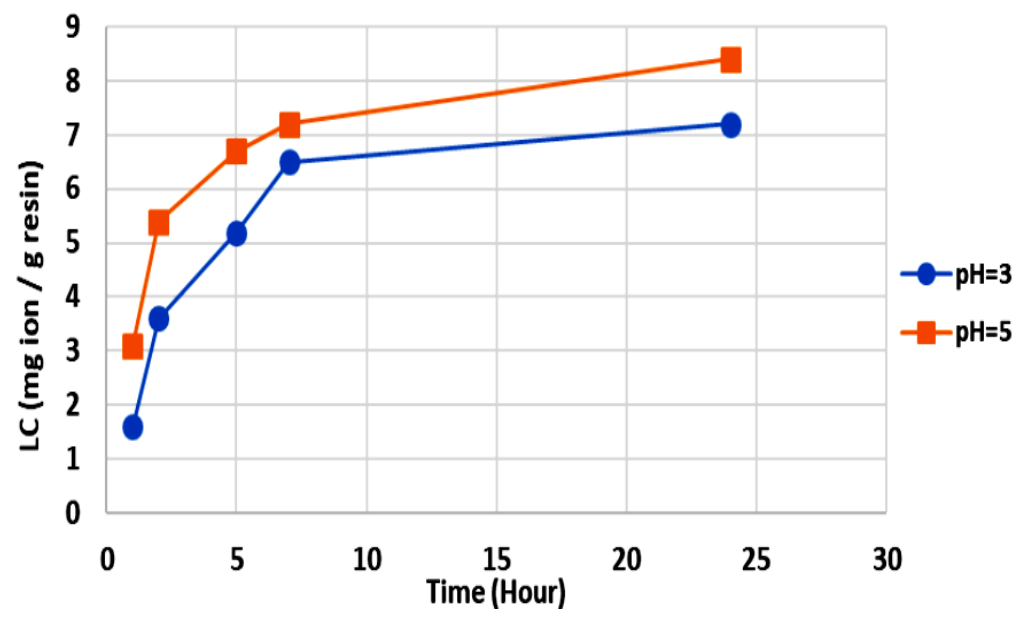

Fig. 15. The number of milligrams of ions $\left(\mathrm{Fe}^{2+}\right)$ withdrawn by $(0.1 \mathrm{~g})$ of the polymer $\left[\mathrm{M}_{7}\right]$ as a function of time in different acidic functions

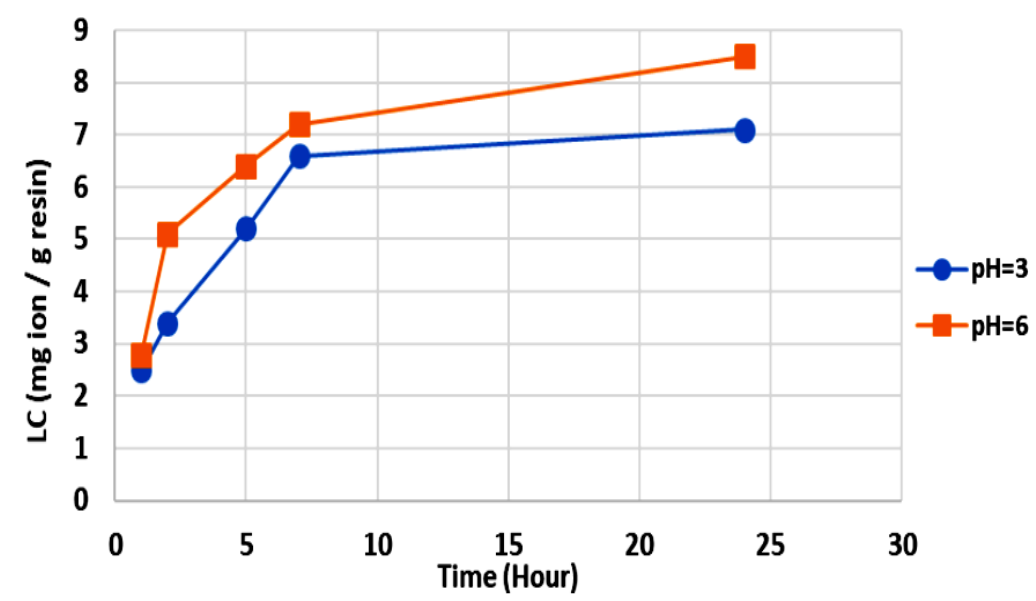

Fig. 15. The number of milligrams of ions $\left(\mathrm{Fe}^{2+}\right)$ withdrawn by $(0.1 \mathrm{~g})$ of the polymer $\left[\mathrm{M}_{7}\right]$ as a function of time in different acidic functions 


\section{ACKNOWLEDGEMENT}

Authors thankfully Acknowledgements the
University of Misan, Department of Chemistry for supporting this work.

\section{References}

1. Almajan, G.L.; Bancescu, S-F.; loana, S.; Gabriel.G.; Draghici, C., European Journal of Medicinal Chemistry., 2010, 45(12): p. 6139-6146. Synthesis and antimicrobial evaluation of some fused heterocyclic $[1,2,4]$ triazolo[3,4-b][1,3,4]thiadiazole derivatives.,

2. Barbuceanu, S.-F.; Almajan, G.L.; Gabriel, A.; Gabriela, L. D.; Constantin, B.; Florica B., European Journal of Medicinal Chemistry., 2012, 49, 417-423. New heterocyclic compounds from 1,2,4-triazole and 1,3,4thiadiazole class bearing diphenylsulfone moieties. Synthesis, characterization and antimicrobial activity evaluation.

3. Desai, S.R.; Laddi, U.; Bennur, R.S.; Patil, P. A.; Bennur, S. Indian Journal of Pharmaceutical Sciences., 2011, 73(1), 115-120. Synthesis and Pharmacological Activities of Some New 3-Substituted-4-Amino-5-Mercapto-1,2,4Triazoles.

4. Küçükgüzel, S.G.; Küçükgüzel, S.; Güniz, R.; Sevim, K.; Muammer. European Journal of Medicinal Chemistry., 2007. 42(7), 893901 . Synthesis of some novel heterocyclic compounds derived from diflunisal hydrazide as potential anti-infective and anti-inflammatory agents.

5. Plech, T.; Wujec, M.; Siwek, A. K.; Urszula, Malm, A., European Journal of Medicinal Chemistry., 2011, 46(1), 241-248. Synthesis and antimicrobial activity of thiosemicarbazides, s-triazoles and their Mannich bases bearing 3-chlorophenyl moiety.

6. Güzeldemirci, N.U.; Küçükbasmacı, Ö. European Journal of Medicinal Chemistry., 2010, 45(1), 63-68. Synthesis and antimicrobial activity evaluation of new 1,2,4-triazoles and 1,3,4-thiadiazoles bearing imidazo[2,1-b] thiazole moiety.

7. Küçükgüzel, I.; Küçükgüzel, S.; Güniz, R.; Sevim, K. Medicinal Chemistry Letters., 2001. 11(13), 1703-1707. Some 3-Thioxo/alkylthio1,2,4-triazoles with a substituted thiourea moiety as possible antimycobacterials.

8. Mavrova, A.T.; Wesselinova, D.; Tsenov, Y. A.; Denkova, P. European Journal of Medicinal Chemistry., 2009, 44(1), 63-69. Synthesis, cytotoxicity and effects of some 1,2,4triazole and 1,3,4-thiadiazole derivatives on immunocompetent cells.

9. Gozzi, G.J.; Pires, Amanda do Rocio A. V.; Glaucio, R.; Maria, E. M.; Glaucia, R.; Noleto, G. R. A.; Alexandra, A. S.; Carlos, E. E; Aurea, M.R.; Camilla, P.; Attilio, S. C.C.; Sílvia M. PLoS ONE., 2015, 10(6), e0130046. Selective Cytotoxicity of 1,3,4-Thiadiazolium Mesoionic Derivatives on Hepatocarcinoma Cells (HepG2).

10. Barbuceanu, S.-F.; Stefania-Felicia, I.; Diana, C. S.; Gabriel U.; Valentina D. C. Radulescu, V., International Journal of Molecular Sciences., 2014, 15(6), 1090810925. Synthesis and Antioxidant Activity Evaluation of New Compounds from Hydrazinecarbothioamide and 1,2,4-Triazole Class Containing Diarylsulfone and 2,4Difluorophenyl Moieties.

11. El-Moghazy, S.M.; Samir, M. B.; Flora, F.; Abdel-Rahman, H.; Marzouk, M.; Adel, A. Medicinal Chemistry Research., 2012, 21(8), 1722-1733. Synthesis and anti-inflammatory activity of some pyrazole derivatives.

12. Pattanayak, P.; Sharma, R.; Sahoo, P.K. Chemistry Research., 2009, 18(5), 351-361. Synthesis and evaluation of 2-amino-5sulfanyl-1,3,4-thiadiazoles as antidepressant, anxiolytic, and anticonvulsant agents. 